\title{
Flipped Classroom in teaching nursing management: experience report
}

\author{
Flipped Classroom no ensino de gerenciamento em enfermagem: relato de experiência \\ Flipped Classroom en la enseñanza de la gestión en enfermería: relato de experiencia
}

\author{
Jouhanna do Carmo Menegaz ${ }^{1}$ (iC) \\ Geyse Aline Rodrigues Dias ${ }^{1}$ \\ Ricky Falcão Silva Trindade ${ }^{1}$ \\ Suzayne Naiara Leal ${ }^{1}$ \\ Nathalia Karym Araújo Martins ${ }^{1}$
}

1. Universidade Federal do Pará.

Belém, PA, Brasil.
Corresponding author:

Jouhanna do Carmo Menegaz.

E-mail: jouhanna@ufpa.br

Submitted on $10 / 20 / 2017$.

Accepted on 02/08/2018.

DOI: 10.1590/2177-9465-EAN-2017-0312

\section{Abstract}

Objective: To report the experience of the use of two Flipped Classroom methods in the curricular activity of the Health Services Organization of an undergraduate nursing course. Method: Report of teaching experience developed in the second half of 2016 and the first 2017 through the introduction of Just in Time Teaching and Peer Instruction into three programmatic content. Results: The flipped methods were introduced into two classes. Peer Instruction and Just in Time Teaching were introduced in class one, in organizational alignment classes and administrative process, respectively. In class two, only Just in Time Teaching, in labour process and administrative process classes. Conclusion: Students had difficulty integrating the individual study. Isolated insertion initiatives may hinder teacher planning and pedagogical structuring of content approach.

Keywords: Nursing; Teaching; Flipped Classroom.

\section{Resumo}

Objetivo: Relatar a experiência do uso de dois métodos de Flipped Classroom na atividade curricular Organização dos Serviços de Saúde de um curso de graduação em enfermagem. Método: Relato de experiência de ensino desenvolvida no segundo semestre de 2016 e no primeiro de 2017 por meio da introdução de Just in Time Teaching e Peer Instruction em três conteúdos programáticos. Resultados: Os métodos flipped foram introduzidos em duas turmas. Na turma um foram introduzidos o Peer Instruction e o Just in Time Teaching, em aulas de alinhamento organizacional e processo administrativo, respectivamente. Na turma dois, apenas o Just in Time Teaching, em aulas de processo de trabalho e de processo administrativo. Conclusão: Os estudantes tiveram dificuldade com a integração do estudo individual. Iniciativas isoladas de inserção podem dificultar o planejamento do professor e a estruturação pedagógica de abordagem do conteúdo.

Palavras-chave: Enfermagem; Ensino; Sala de Aula Invertida.

\section{Resumen}

Objetivo: Relatar la experiencia del uso de dos métodos de Flipped Classroom en la actividad curricular Organización de los Servicios de Salud de curso de graduación en enfermería. Método: Relato de experiencia de enseñanza desarrollada en el segundo semestre de 2016 y en el primero de 2017 a través de la introducción de Just in Time Teaching y Peer Instruction en tres contenidos programáticos. Resultados: Los métodos flipped se introdujeron en dos clases. En la clase uno se introdujeron el Peer Instruction y el Just in Time Teaching, en clases de alineación organizacional y proceso administrativo, respectivamente. En la clase dos, sólo el Just in Time Teaching, en clases de proceso de trabajo y de proceso administrativo. Conclusión: Los estudiantes tuvieron dificultad con la integración del estudio individual. Las iniciativas aisladas de inserción pueden dificultar la planificación del profesor y la estructuración pedagógica de enfoque del contenido.

Palabras clave: Enfermería; Enseñanza; Clase Inversa 


\section{INTRODUCTION}

The role of the university, students and professors teachers, teaching methods and content ${ }^{1,2}$ have been the subject of discussion not only in nursing, but also for researchers from various fields, such as dentistry, medicine and physical education.

In an ever-changing world, it has been necessary to rethink the relevance of teaching with teacher-centered approaches and content to teach with student-centered approaches and their learning processes, ${ }^{3}$ since they have a greater potential to promote competency learning and not only apprehension of knowledge.

Student-centered approaches imply pedagogical designs in which not only teachers assume the responsibility of identifying and monitoring teaching objectives, but in which students select and incorporate their own means of learning based on engagement, ${ }^{4}$ allowing them not only to memorize, but to act in order to learn. There is a set of pedagogical models and methods with potential to conduct student-centered approaches and in this text we will highlight the Flipped Classroom method.

Flipped Classroom is a pedagogical model that consists of the inversion of the traditional sequence of content-centric approaches, characterized by '1-2-3', corresponding to: (1) teaching, (2) individual study and (3) evaluation to 2-3-1, individual study, evaluation and teaching. However, the change in the proposed teaching process lies not only in the inversion of the sequence, but in the assumability of pedagogical principles such as the need for commitment, engagement, engagement, dialogue and reflection. ${ }^{5}$

There are several Flipped Classroom methods as there is not a single right way or watertight method. Therefore, maintaining the centrality on the student and the inversion of the traditional sequence, teachers can choose what they consider most relevant to their discipline and adapt according to their content and context. Regarding benefits to students and their learning, an increase in performance accompanied by an increase in motivation and belief in their effectiveness in performing activities is highlighted. ${ }^{6}$

Considering how nurses are trained to work in health systems and services at various levels of care, in which, in order to competently perform care and management dimensions, knowledge is required but also the presence of skills and attitudes to deal with dilemmas, and obscure areas of practice that may be unexplored and for which the answers are not found in books, ${ }^{7}$ it seems pertinent to invest in practical-reflexive teaching proposals such as those outlined by Flipped Classroom methods.

When analyzing the potential of the Flipped Classroom methods for nurse training, the following question was presented: How to introduce Flipped Classroom methods in a health services management discipline taught in a nursing undergraduate course? Therefore, the objective of this text is to report the experience of using two Flipped Classroom methods in the Health Services Organization curricular activity of a nursing undergraduate course.

\section{THEORETICAL FRAMEWORK: PRACTICAL-REFLEXIVE TEACHING, FLIPPED CLASSROOM AND THE STUDENT-CENTERED APPROACH}

A set of concepts provided support to this experience. The concepts of practical-reflexive teaching and Flipped Classroom introduce the idea of the student-centered approach, proposing ways of doing it. Its adoption shows the intention of schools and teachers to create pedagogical designs for disciplines, classes and lessons in which students can learn by doing and are at the center of the process..$^{7,8}$

The student-centered approach appears to substantially contribute to the promotion of autonomy, as well as facilitating meaningful learning, as the teacher plays the role of process advisor. ${ }^{7}$ Thus, the student has a role beyond retaining information, being able to give meaning and understanding information and, from their previous knowledge, create new knowledge and apply it to real situations.

Practical-reflexive teaching is based on the premise that the student learns through doing or performing. It is argued that students can not teach what they need to know, but one can engage them in activities in which they learn. Therefore, it is the responsibility of the school and the teachers to instruct and create the conditions so that they can, even in an assisted way, do and learn. To do so, the pedagogical lesson design should allow them to understand know and reflect on the action. ${ }^{7}$

By using Flipped Classroom and a set of loosely structured methods, it is possible to engage them in content exploration, which based on certain methods, allows for the exercise of performance. Therefore, it is possible to focus on content, as traditional approaches do, but to transcend it while stimulating individual study and the best use of teacher-student time.

Considering the study-evaluation-teaching inversion, it is noticed that when the student prepares before the class, the pedagogical meeting becomes an active space, not only for explaining the basics, but with questions, discussions and practical activities. The teacher works on the students' difficulties rather than just presenting the content of the subject, making the teaching experience more personalized. ${ }^{9}$

In order to provide this preparation, Flipped Classroom made use of blended learning, which is the composition and programming of distance activities supported by technological resources and face-to-face activities. It is strongly associated with flipped and emerges as a positive strategy to support studentcentered approaches, since its introduction allows teaching of a subject to be a continuous process and pedagogically available to students in a timely manner according to their needs. ${ }^{10}$

Some flipped models have been applied to higher education courses, mainly as an initiative to meet the challenge of guaranteeing learning, inherent in the teaching-learning process. These methods have succeeded in transforming the dynamics of the classroom, achieving positive results in the conceptual learning of scientific contents and even in the development of cognitive and social skills. ${ }^{11}$ 


\section{PEER INSTRUCTION AND JUST IN TIME TEACHING: AN APPROACH}

Peer Instruction (PI) was developed by Professor Eric Mazur at Harvard University in the 1990s. It contains four steps: 1. Brief lesson on content; 2. Application of ConcepTest; 3. Voting and counting of responses; 4 . The teacher's action according to the percentage of answers (Figure 1).

Step 1 provides that the teacher limits the initial exposure of the content to a few minutes. In step 2, the multiple-choice ConcepTest (conceptual question) is applied and is answered individually by the students in a pre-established time. In step 3 the voting is opened in order to map student responses using Clickers (electronic device that communicates with the teacher via radio frequency) or flashcards. Finally, in step 4, from the percentage of correct answers the teacher reviews the content and repeats the test individually, in pairs, or moves on to a new topic. ${ }^{12}$

Just In Time Teaching (JiTT) was proposed by Professor Gregor Novak and collaborators in the early 1990s at Purdue University in Indianapolis, USA. The JiTT consists of the following steps: 1. Making material available and sending Warm-ups in advance by electronic means; 2 . Students' performance of online Warm-ups; 3. The teacher receives, analyzes the answers and reformulates the lesson plan; 4. Adapted class (Figure 2).

The first step consists in sending the material and Warm-ups by electronic means; in step 2 the Warm-ups must be answered and sent to the teacher within 24 hours before the next class. The main objectives of the Warm-ups are to arouse interest in the subject in the students and form a basis for a deeper understanding. ${ }^{12}$

In step 3, the answers are checked and analyzed so that the teacher can perceive both the previous level of knowledge of the class and their difficulties on the proposed theme. Finally, in the fourth stage, based on the answers obtained, the teacher adapts the class to points that he or she considers most important for the learning process of the class and selects some answers from the students to discuss during the class. ${ }^{12}$

The literature suggests that JiTT encourages students to examine their prior knowledge and seek conceptual information on the proposed content before class, helping them to take responsibility for their learning. ${ }^{13}$

\section{METHODOLOGICAL ROUTE}

The undergraduate nursing course at UFPA, created in 1975 , has a total workload of 4875 hours, which is divided into nine semesters. Each semester is connected to thematic units that cover curricular activities. The Health Services Organization curriculum activity, in which the experience was conducted, takes place in the 5th semester of the undergraduate nursing course at UFPA, in the Planning and Management in Nursing and Development of Pedagogical Practices thematic units. ${ }^{14}$

The Health Services Organization curricular activity has a total workload of 170 hours, 85 hours are theoretical and 85 hours are practical. It covers the study of the historical and theoretical context of the administrative process, with emphasis on social development, organization of health policies and its application to nursing, ${ }^{14}$ with weekly classes taught on Mondays ( 2 hours) and Fridays (3 hours). It has a faculty composed of two permanent professors.

The curricular activity proposes the development of the following competences and abilities: (1) To interpret the social process of institutionalization under functionalist and institutionalist approaches; (2) Form conceptual elements on the origin, development, classification, hierarchical levels, alignment

Figure 1. Peer Instruction Steps.

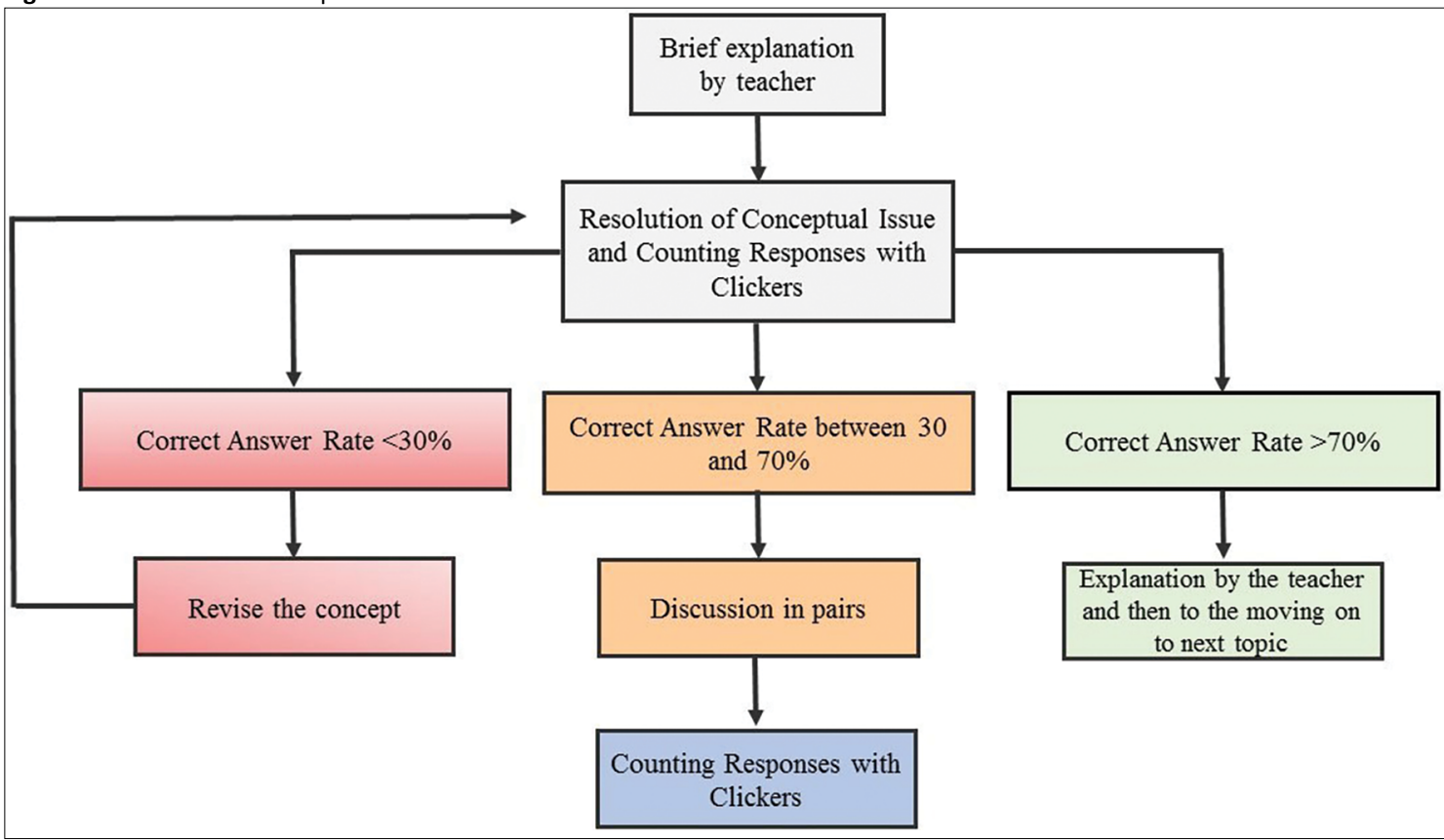




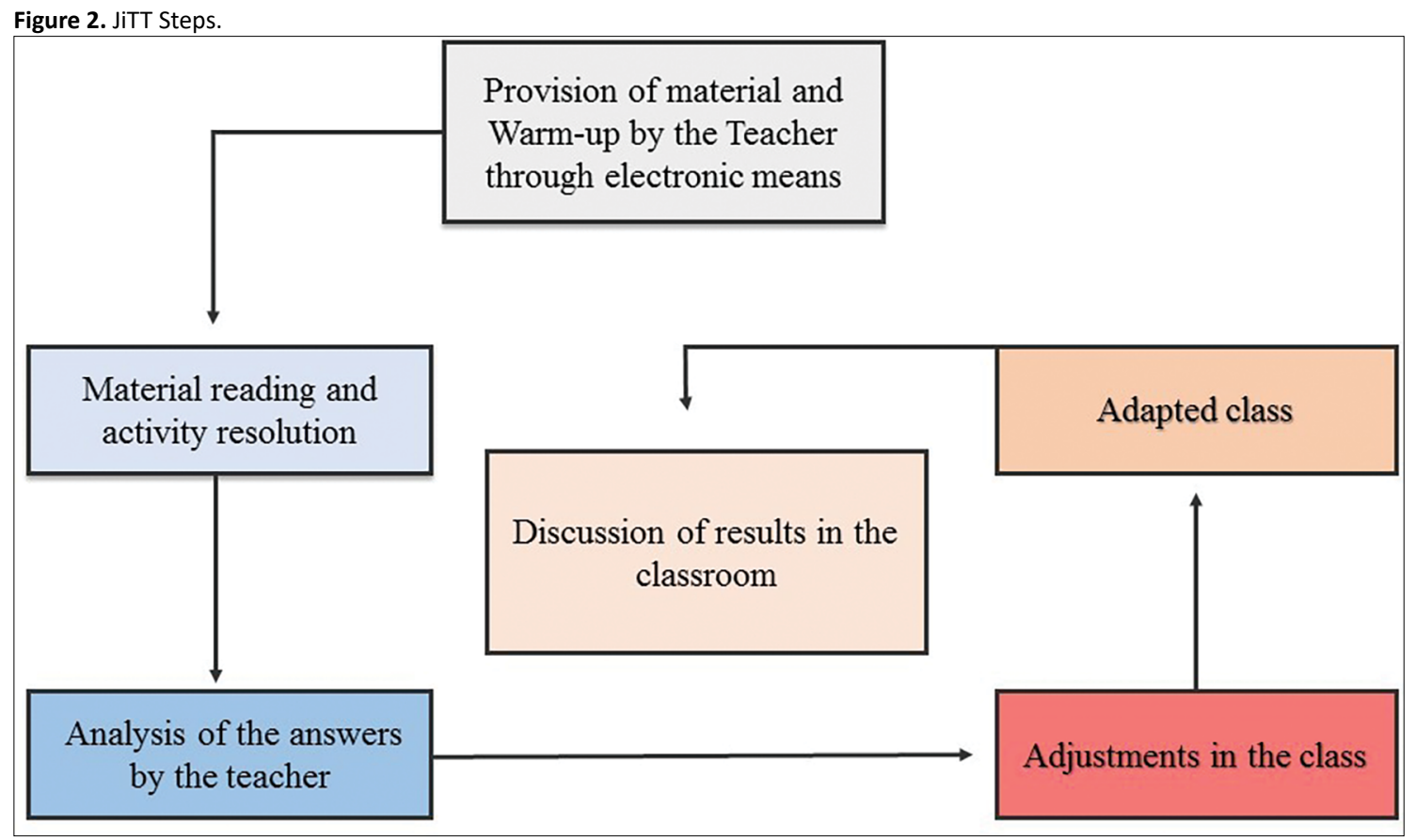

and resources of formal organizations in general to the health and nursing organizations; (3) Define the labour process in general and its constituent elements, relating it to healthcare work and nursing in the areas of care and management; (4) To identify the evolutionary phases of the General Theory of Administration (TGA) and influences of its main theories in the practice of nursing management; (5) Define mechanisms for the development of the administrative process in formal organizations - functions and instruments.

Each of these five competencies is developed in a thematic unit of curricular activity. Competencies 2, 3 and 5 were fostered with the help of Flipped Classroom methods.

\section{DESCRIPTION OF THE EXPERIENCE}

The introduction of the flipped methods was performed from August 2016 to March 2017 in two distinct class groups, which will be named 1 and 2 . Class 1 had 31 students and class 2 had 36 students. The intention was to test the feasibility of implementation and student acceptance. All classes were taught on Fridays, and lasted 3 hours.

In class group 1, PI and JiTT were introduced in organizational alignment classes and administrative process classes, respectively, complying with competencies 2 and 5 . In class group 2, only JiTT, in classes of labour process and administrative process, complied with the competencies 3 and 5 . Chart 1 summarizes the elements that guided the use of the methods in each content.

In class group 1, the JiTT was the first method included in the Administrative Process class. The material and Warm-ups were made available via Google Drive, one week in advance, and the students posted their answers up to 48 hours before class. Based on the students' answer, the class, whose base was already created in relation to the objective, was directed to the aspects in which they presented difficulties or needed a new understanding. Correct answers were also selected to illustrate conceptual understanding, when demonstrated.

The JiTT was used according to the classical proposal, without adaptations. However, the second method, i.e. the $\mathrm{PI}$ method used in the Organizational Alignment class, was adapted. The material was e-mailed to the students, also one week in advance, and the questions were answered in groups, not individually. There was no exact control of the frequency of correct answers, since clickers or other devices were not used to allow real-time counting for the percentage of correct and wrong answers. There was also no discussion in fixed pairs for the purpose of conceptual enlightenment.

Each question was projected, time was given for discussion, and then the groups responded and discussed with each other and with the professor, moving immediately to the next question. When a wrong answer or the emergence of a doubt in the group appeared, the student addressed the class and any other student from another group, who had understood the concept, and tried to explain the doubt.

These flipped methods were chosen to favor conceptual apprehension, through individual study and approximation and resizing based on responses to related issues, which is relevant to theoretical content. Thus, the Warm-ups in the JiTT and the $\mathrm{PI}$ questions were constructed to contemplate all concepts of interest foreseen in the teaching plan for each of the classes in which the methods were included.

In class group 2, only JiTT was introduced, first in the labour process class and then in the administrative process class. The individual study material and the Warm-ups were made 
Chart 1. Implementation Detail by Content.

\begin{tabular}{|c|c|}
\hline \multicolumn{2}{|r|}{ Administrative Process } \\
\hline Method & Just in Time Teaching \\
\hline Class objective & $\begin{array}{l}\text { Define mechanisms for the development of the administrative process in formal } \\
\text { organizations - functions and instruments. }\end{array}$ \\
\hline Material & Administrative process video available on YouTube ${ }^{\circledR}$. \\
\hline Warm-ups & $\begin{array}{l}\text { 1. In your words, say what you understand by administrative process; } \\
\text { 2. We saw in the video that the administrative process has four functions. Cite them } \\
\text { and give an example for each role in the nurses' context; } \\
\text { 3. From your understanding, do nurses use the administrative process in their daily } \\
\text { work? Justify. }\end{array}$ \\
\hline Work concepts & $\begin{array}{l}\text { Administrative process; } \\
\text { Systematics; } \\
\text { Goal; } \\
\text { Theoretical basis and functions (planning, organization, direction and control). }\end{array}$ \\
\hline Participation & 21 students in class group 1 and 29 in class group 2. \\
\hline \multicolumn{2}{|r|}{ Labour process } \\
\hline Method & Just in Time Teaching \\
\hline Class objective & Define the labour process in general and its constituent elements. \\
\hline Material & Chapter 5 of "The Capital", volume 1, by Karl Marx: Labor and the Valorization process. \\
\hline Warm-ups & $\begin{array}{l}\text { 1. What is work? } \\
\text { 2. In what way is the work developed? } \\
\text { 3. Why do people work? } \\
\text { 4. How important is work to you? } \\
\text { 5. How do you perceive work in our society? }\end{array}$ \\
\hline Work concepts & $\begin{array}{l}\text { Work; } \\
\text { Labour process; } \\
\text { Constitutive elements (activity oriented to an end, object, instruments). }\end{array}$ \\
\hline Participation & 32 students from class group 2 \\
\hline \multicolumn{2}{|r|}{ Organizational Alignment } \\
\hline Method & Peer Instruction \\
\hline Class objective & $\begin{array}{l}\text { Forming conceptual elements on hierarchical levels, alignment and resources of formal } \\
\text { organizations in general to the health and nursing organizations. }\end{array}$ \\
\hline Material & E-book Endeavor, by Daniel Castello, "How to Build Your Business Identity". \\
\hline Questions asked in the classroom & $\begin{array}{l}\text { Eight multiple choice questions performed in the classroom. Example: } \\
\text { Regarding organizational values, say whether the statement is true (T) or false (F). } \\
\text { ( ) It is possible to say that there are essential values of aspiration and accidental } \\
\text { values. } \\
\text { ( ) They are needed in an organization only to achieve goals and not to cultivate a } \\
\text { sense of justice and belonging, stimulating a good organizational culture. } \\
\text { ( ) They express the identity of an organization in actions. }\end{array}$ \\
\hline Work concepts & $\begin{array}{l}\text { Organizational Alignment; } \\
\text { Mission; } \\
\text { View; } \\
\text { Values and Principles. }\end{array}$ \\
\hline Participation & Two students performed reading in advance and 29 participated in the room. \\
\hline
\end{tabular}


available in the same way and with the same deadline as they were for class group 1 .

\section{Experience Analysis}

The use of the flipped methods was perceived as an innovation in the education process, as it changed the dynamics of pedagogical organization and teaching. Previously, the professor used the same presentation and content and the students were only used to this method of traditional teaching, known as teacher-centered method, now they were introduced to the inversion and the student-centered approach method. However, there are issues that need to be considered for the success of future experiences, especially the preparation of the classes by the professor and the characteristics of the students.

The flipped methods were introduced along with traditional teaching approaches such as lectures. The introduction of JiTT and PI made an impact. From the teaching perspective, the greatest demand highlighted was in relation to time and class preparation, ${ }^{15}$ because even if the professor already possesses material and masters the content in question, it will still be necessary for the teacher to delineate the class for the class profile, constantly adapting it.

The Flipped Classroom methodology requires the engagement of teachers, who must plan every step of each method, and even predict what difficulties may arise during its development. ${ }^{12}$ In addition, it also requires student engagement, as it differs from traditional, teacher-centered teaching methods. Thus, it aims to develop student autonomy and protagonism, however, doing the previous readings and study routines outside the classroom will depend on the characteristics of each one.

Regarding the students, it was noticed that the greatest difficulties were the use of the Internet for studying purposes and the programming of deadlines for reading and sending the tasks. The two methods, JiTT and PI, consisted in providing online materials that addressed the topic that would be taught in the classroom, such as videos, texts and questionnaires. A portion of the students did not perform the reading or proposed activities, claiming that they did not do so because they did not have access to the Internet outside the institution or did not check their e-mail accounts daily.

According to the Exame Nacional de Desempenho dos Estudantes/National Student Achievement Examination Report (ENADE), ${ }^{16}$ the majority of nursing students, $42 \%$, only study for one to three hours per week, which is considered insufficient time for reading, studying, and understanding and which, together with the difficulty in accessing the Internet, compromises the development of flipped methods with blended learning. Flipped methods always originate from individual study and demand that students are accountable for their learning, which is not only delegated by the teacher and the time in class. Thus, it is also a change of culture, in which students would have to be aware of their responsibility, organizing themselves to include individual study time in their routine. ${ }^{4}$
In spite of the difficulty with the individual study and sending the activities, when in the classroom, the experience seemed to allow the students to reflect on the importance of their participation at all stages and on the purpose of developing their own learning. ${ }^{2}$ It may be helpful for the teacher, in his/her own adaptation period and for the students, to create alternative ways to send reminders to students regarding classroom notes, reading material, and related tasks and their respective deadlines until students adapt to this new dynamic. Grading the activities could also be an alternative in this adaptation period as students tend to prioritize activities which will be graded.

It should also be highlighted that, since different methods have been used, it has been observed that alternation can be beneficial, since students do not have the same preferences or learn in the same way and the student may not grasp how well he or she should act in each class, and have more difficulty in participating. This question must be considered and evaluated by the teacher who, depending on the pedagogical objective and the characteristics of the class, should choose the most appropriate methods.

Students in class group 1, who experienced both methods, showed a preference for JiTT rather than PI. More tasks were send for JiTT class as well as more participation and interaction. In comparison, when the PI was used, there was less participation, as many did not read the available text and consequently did not interact nor participated in the activity, causing the class to be dispersed.

This may be justified because the material sent to the JiTT class group was a video and the material sent to the PI class group was a text, which reinforces the relevance of pedagogical knowledge of teacher content and knowledge regarding students and their characteristics. ${ }^{17}$

Another aspect to be considered in the use of PI has to do with the lesson preparation. It has been realized that the use of very simple multiple-choice questions can complicate the method application. Questions need to be developed that require students to reason in the choice of their answers and require that they have previously studied the material provided. Otherwise, by association or logic, they will be able to answer the questions correctly, which will not stimulate the actual content assimilation, nor discussion. ${ }^{18}$

Continuing on the subject of the preparation of the lesson for the use of this method, it is worth noting that counting is crucial. If the university or the course adopts the PI method in some disciplines and has available funds, investing in the purchase of clickers is valid. ${ }^{17}$ Another alternative is the use of the Socrative ${ }^{\circledR}$ software, which has a mobile version and allows the student to participate in the class using a cell phone or tablet. However, there may be at least two situations where the use of in-room software is not recommended: if students do not have access to these devices and the university does not have access to the internet. 


\section{FINAL CONSIDERATIONS}

Considering the objective of reporting the experience of using two Flipped Classroom methods, we believe that this text can stimulate nurse educators to reflect on the teaching which we provide, the role of their actors, the potentialities of the changes, as well as their possible obstacles.

By adopting flipped methods, one constantly learns, a new experience is created with each class, which encourages us to continue moving, reflecting and understanding that learning does not reside in transmission and is not concluded in the act of teaching if the learner does not become aware, empowered or takes responsibility. It is up to the teacher to have excellent preparation as well as constant improvement and encouragement.

Regarding the perception of content learning in which flipped methods were used, despite the reported limitations in relation to the individual study, we believe that the students, when experiencing the methods, had the opportunity to experience multiple contacts with the content, assimilating each of them, and when in a traditional class this is scheduled to occur only once, with the teacher. It was also possible for them to argue and relate new content with previous experiences, and possibly expand their understanding.

It was also noticed that using isolated initiatives of flipped methods, in some classes and not others, can hamper teacher planning and pedagogical content structuring. It seems more interesting to use the same method per unit, i.e., in a set of four or five sequential classes, which would also favor the students' adaptation, especially in the case of their first experience with the flipped method.

As a result of learning from this experience, the use of the flipped methods per unit is being expanded, with, Team Based Learning being added to Just In Time Teaching and Peer Instruction. There is also a study on the main difficulties encountered by students in the use of flipped methods. Additional studies are suggested in different contexts and disciplines.

\section{REFERENCES}

1. Bengsten S, Barnett R. Confronting the Dark Side of Higher Education. J Philos Educ [Internet]. 2017; [cited 2016 Dec 5]; 51(1):114-31. Available from: http://onlinelibrary.wiley.com/doi/10.1111/1467-9752.12190/epdf

2. Lima MM, Reibnitz KS, Kloh D, Vendruscolo C, Corrêa AB. Diálogo: rede que entrelaça a relação pedagógica no ensino prático-reflexivo. Rev Bras Enferm [Internet]. 2016 Jul/Aug; [cited 2016 Dec 5]; 69(4):654-61. Available from: $h$ ttp://dx.doi.org/10.1590/0034-7167.2016690406i

3. Guzmán-Valenzuela C, Barnett R. O desenvolvimento da autocompreensão em posturas pedagógicas: explicitando o implícito entre os novos docentes. Educ Pesqui [Internet]. 2013; Oct/Dec; [cited 2016 Dec 5];39(4):891-906. Available from: http://dx.doi.org/10.1590/S151797022013005000013
4. Hannafin MJ, Hill JR, Land SM, Lee E. Student-Centered, Open Learning Environments: Research, Theory, and Practice. In: Spector J, Merrill M, Elen J, Bishop M, eds. Handbook of Research on Educational Communications and Technology. New York (NY): Springer; 2014. p. 641-51. [cited 2016 Dec 5]. Available from: https://link.springer.com/ chapter/10.1007/978-1-4614-3185-5_51

5. Tucker B. The Flipped Classroom: Online instruction at home frees class time for learning. Educ Next [Internet]. 2012; [cited 2016 Dec 5]; 12(1):823. Available from: http://educationnext.org/the-flipped-classroom/

6. Thai NT, De Wever B, Valcke M. The impact of a flipped classroom design on learning performance in higher education: Looking for the best "blend" of lectures and guiding questions with feedback. Comput Educ [Internet] 2017 Apr; [cited 2016 Dec 5]; 107:113-26. Available from: http://www. sciencedirect.com/science/article/pii/S0360131517300039?via\%3Dihub

7. Schön DA. Educando o profissional reflexivo: um novo design para o ensino e a aprendizagem. Tradução de Roberto Cataldo Costa. Porto Alegre: Artmed; 2000.

8. Gillispie V. Using the flipped classroom to bridge the gap to generation Y. Ochsner J [Internet]. 2016; [cited 2017 Oct 10]; 16(1):32-6. Available from: https://www.ncbi.nlm.nih.gov/pmc/articles/PMC4795497/

9. EDUCAUSE Learning Initiative (ELI). 7 Things you should know about flipped classrooms. 2012. [cited 2016 Oct 19]. Available from: http://net. educause.edu/ir/library/pdf/eli7081.pdf

10. Domínguez LC, Veja NV, Espitia EL, Sanabria AE, Corso C, Serna AM, et al. Impacto de la estrategia de aula invertida en el ambiente de aprendizaje en cirugía: una comparación con la clase magistral. Biomédica [Internet]. 2015; [cited 2017 Oct 10]; 35:513-21. Available from: https://www. revistabiomedica.org/index.php/biomedica/article/viewFile/2640/2939

11. Rui Z, Lian-Rui X, Rong-ZhengY, Jing Z, Xue-Hong W, Chuan Z. Friend or Foe? Flipped Classroom for Undergraduate Electrocardiogram Learning: a Randomized Controlled Study. BMC Med Educ [Internet]. 2017 Mar [cited 2017 Oct 10]; 17(1):53. Available from: https://www.ncbi.nlm.nih $\mathrm{gov} / \mathrm{pubmed} / 28270204$

12. Novak GM. Just-in-time teaching. New DirTeach Learn [Internet].2011; [cited 2016 Dec 5]; 128:63-73. Available from: http://dx.doi.org/10.1002/tl.469

13. Schuller MC, DaRosa DA, Crandall ML. Using just-in-time teaching and peer instruction in a residency program's core curriculum: enhancing satisfaction, engagement, and retention. Acad Med [Internet]. 2015 Mar [cited 2017 Oct 10]; 90(3):384-91. Available from: https://www.ncbi.nlm. nih.gov/pubmed/25426736

14. Universidade Federal do Pará. Instituto de Ciências da Saúde. Faculdade de Enfermagem . Projeto pedagógico do curso de graduação em enfermagem. Belém: UFPA; 2008.

15. Rodrigues CCFM, Carvalho DPSRP, Salvador PTCO, Medeiros $\mathrm{SM}$, Menezes RMP, Ferreira Júnior MA, et al. Ensino inovador de enfermagem a partir da perspectiva das epistemologias do Sul. Esc Anna Nery [Internet]. 2016; [cited 2016 Dec 5]; 20(2):384-9. Available from: http://www.redalyc.org/articulo.oa?id=127745723026

16. Ministério da Educação (BR). Relatório de Área ENADE 2013: Exame Nacional de Desempenho dos Estudantes. Enfermagem. Brasília (DF) Ministério da Educação; 2013.

17. Menegaz JC, Backes VMS. Bons professores de enfermagem, medicina e odontologia: Percepção acerca do conhecimento sobre os alunos. Esc Anna Nery [Internet]. 2016; [cited 2016 Dec 5]; 20(2):268-74. Available from: http://www.scielo.br/pdf/ean/v20n2/1414-8145-ean-20-02-0268.pd

18. Sayer R, Marshman E, Singh C. Case study evaluating Just-In-Time Teaching and Peer Instruction using clickers in a quantum mechanics course. Phys Rev Phys Educ Res [Internet]. 2016 Jul/Dec; [cited 2016 Dec 5]; 12(2):020133. Available from: https://link.aps.org/doi/10.1103/ PhysRevPhysEducRes.12.020133 